\title{
A Review of the Recent Trends in the Relationship between Unemployment and Families
}

\author{
Moushumi Roy Choudhury and Clifford L. Broman \\ Michigan State University
}

* Please address correspondence to Moushumi Roy Choudhury, PhD, and Clifford L. Broman, PhD, at Michigan State University, Department of Sociology, 509 E. Circle Drive, East Lansing, MI 48824. Emails: broman@msu.edu and mroyc77@gmail.com.

\begin{abstract}
Past research shows that economic instability, financial hardship, and job loss can have profound impact on the well-being of individuals and family. Equipped with new findings, we return to the critical review of the impact of job loss on family formation. This review follows from and updates the prior research data on the impact of broadly defined economic hardship on families. Our findings indicate that the relationship between unemployment and family is multifaceted and multilevel. Furthermore, a closer look at the family dynamics show that structural economic transformations move beyond the loss of income further speeding up a momentum of social downfall. More specifically, the socially constructed economic transformation embodies powerful mechanisms that lead to intergenerational family outcomes. While we find the positive effects of family resiliency during periods of structural instability, based on our critical analysis of the past research we advocate for urgent and overtime social and economic welfare support to the families during the times of crisis until their socioeconomic stability with proactive structural engagement.
\end{abstract}

Keywords: unemployment, job loss, economic instability, impact, family dynamics, well-being

\section{Introduction}

This update focuses on the impact of unemployment on families. Research has found that economic instability, job loss, and financial hardship can have profound impacts on the well-being of individuals, but also on the family. 


\section{Background and Prior Research}

Prior research on this topic has pointed out a number of findings. First, the research on unemployment and families has shown that not all individuals will react equally to a given event, though job loss is considered to be a stressful experience to most people. In our view, the loss (or anticipated loss) of work has stressful effects through two major pathways. First, job loss brings on financial hardship to individuals and families. Job loss brings loss of an income. In our society, many families deem having two earners to be vital to financial survival. Thus the loss of an income often immediately poses a threat to a family's wellbeing. Families must attempt to live off of a single salary, any savings they may have, and whatever modest contributions unemployment benefits provide, should they be fortunate to have either savings or qualify for unemployment benefits. Second, the job loss itself and financial hardships that ensue can each erode the worker's sense of self-worth and self-control. In our society, an individual's identity and self-worth is often tied to employment. Employment provides a sense of purpose; a sense that one does something of worth and is compensated accordingly. This link between self-worth and employment may be particularly strong for men. Many men, particularly those in families, find their sense of worth tied up in their ability to provide for their family. With job loss comes not only a loss of income, but a loss of their source of identity and value (Townsend, 2002).

As we conceptualize it, the stress process begins with a loss or threat event. This threat event sets in motion a series of reactions with both physical (a la Selye's General Adaption Syndrome) and emotional reactions. Anxiety and depression are common results of the experience of stress (Broman, Hamilton, \& Hoffman, 1990). Depression is a logical result of job loss, for all the reasons discussed above. Anxiety stems from a fear that one will be unable to cope with a hidden, imagined, or fully-in-view peril. This is why studies have found that not only actual job loss but also anticipating job loss is extremely stressful (Broman, Hamilton, \& Hoffman, 1990). For this reason, during periods of widespread economic hardship, individuals may experience detriments to their psychological well-being regardless of their personal employment situation. Witnessing one's family members, neighbors, friends, and coworkers lose their jobs can serve as a threat event in its own right.

The literature clearly indicates the significance of stress on personal wellbeing, and indicates that unemployment and associated financial hardship often serve as a source of considerable and chronic stress (Kessler, Turner \& House, 1987). Further, stressful situations reverberate around the individual going through the stressful event. Researchers from a variety of academic fields have found that financial hardship and the experience of being unemployed can affect both mental and physical health (see, for example, Adler \& Ostrove, 1999; Dooley, Fielding, \& Levi, 1994; Gore, 1978; Hamilton, Broman, Hoffman, \& Renner, 1990; Kessler, Turner, \& House, 1988; Paul \& Moser, 2009; Price, Choi, \& Vinokur, 2002). Though the topic has been less investigated, researchers have also found evidence that unemployment and financial hardship affect not only the individual without a job, but can impact other family members and family dynamics (Conger \& Conger, 2002; Conger, Ge, Elder, Lorenz, \& Simons, 1994; 
Edler \& Caspi, 1988; Takeuchi, Williams, \& Adair, 1991; Voyandoff, 1990). Studies have linked the stress of unemployment to an increase in family conflict and arguments (Broman, Hamilton, \& Hoffman, 1990). Others have found evidence that unemployment is associated with higher levels of marital instability (Starkley, 1996) and intimate violence (Coker, Smith, McKeown, \& King,2000; Straus, Gelles, \& Steinmetz, 1980), though other researchers have found that the risk of domestic violence is increased due to financial strain, not as a result of unemployment per se (Fox, Benson, DeMaris, \& Van Wyk, 2002). Moreover, the stress and tension that result from unemployment and financial hardship can impact children's well-being in both the short and long-term (McLoyd, 1990; McLoyd, Jayaratne, Ceballo, \& Borquez, 1994).

\section{More Recent Research}

On a broader or structural level, family researchers have long noted the significance of interrelationship between the economy and family (McKeever \& Wolfinger, 2012). A lot of time the financial hardship is experienced and explained by unemployment (MacInnes \& Broman, 2012). For example, the Great Recession as a structural reason had a strong impact on the family dynamics. The aftermath of the Great Recession set in the momentum of the great depression. Structural-demographic consequences of the great depression resulted in low fertility rates (McKeever \& Wolfinger, 2012). When translating the great recession into long term unemployment and job losses, a strong association has been found between long term unemployment, job losses and poor socioeconomic outcomes (Nichols, Mitchell, \& Lindner, 2013). The knowledge pertaining to what drives these associations indicates that increased family stress and reduced income are two main factors that are acknowledged as stronger determinants. In the short run, job losses can certainly lead to losses of income. On a permanent basis, however, it can lower wages, result in worse mental and physical health and higher mortality rates (Nichols, Mitchell, \& Lindner, 2013). Furthermore, parental job losses hamper children's educational progress and lower their future earnings. Nonetheless, due to the lack of any clear indication, the connection between longer duration of unemployment and its worsening effects on family stability is weakly explained by the research.

Pertaining to family level dynamics, the effect of job loss, in combination with dismissal and temporary job endings (Doiron, \& Mendolia, 2012) on marital status is increasingly associated with marital instability and dissolution. The nature of unemployment resulting in losing of a job has consequences for long lasting earning losses and financial strains which have greatest probability of family stress, such as difficulty in paying bills, food insecurity and marital conflicts (MacInnes \& Broman, 2012). When factored together, these stressors influence family well-being by increasing marital instability. On the contrary, economic cost effectiveness consideration due to economic hardship led to a different set of findings. It showed that the effect of the Great Recession increased the cost effect of divorce, and in several cases, the loss of job led to the increase of maintenance of one household over two households; this was primarily associated with decline in divorce rate (Artazcoz, Benach, Borrell, \& Cort $\tilde{A}$ “s, 
2004). The interpretation of these outcomes points to the meaning of employment being within and beyond the source for income (Eliason, 2012). While in general job losses increase the chances of divorce, the nature of job loss is usually significant in understanding significance of marital dissolution.

While job loss affects loss of income, it also influences loss of social status and non-confirmation from social status approval (Van der Meer, 2014). Applying social production functional theory, which states that ultimately people strive for physical well-being and social approval, in gender relations determines how unemployment effects might vary for men and women. Accordingly, research has found that social effects are larger for men's unemployment than women's employment (Van der Meer, 2014). Unemployment along with income loss pertains to subjective loss of the individual who lost the job. While employed men and women show no difference in subjective well-being, the same study found that unemployed men show almost $7 \%$ less fall off in subjective well-being than women(Van der Meer, 2014), confirming to the traditional social gender assumption and non-approval from men's self-worth.

Furthermore, linking gender dynamics to married couples, generally it has been argued that if either husband or wife is unemployed, the marital dissolution tends to be the most likely outcome (Tumin \& Qian, 2015). A likely assertion of this effect is that while marriages are affected by both husband and wives job loss, there is a maximum likelihood that husband's job loss leads to increasing level of marital dissolution. This implies unemployed men as poor marital selections than unemployed women (Eliason, 2012). However, considering separation being the precondition of divorce, not all relationships suffer divorce after separation. A study found that men's job loss during separation decreased the probability of divorce after separation, whereas men's unemployment before separation does not show similar outcome (Tumin \& Qian, 2015). While unemployment among men tends to strengthen the significance of relationship between job loss and divorce, the relationship had no association with divorce after separation with women's unemployment either before or during separation. This complexity in the relationship between unemployment, separation, and ultimately divorce is marked by reverse gender roles from traditional gendered mapping. The lack of seriousness among men's unemployment has been interpreted as devaluation of men in the marriage market, hence leading to delaying of formal end of marital relationship (Tumin \& Qian, 2015).

Unemployment affects not only the individual who has lost a job, but also other family members, including intergenerational relationships. For example, it is found that women, who are more likely to suffer marital dissolution, mostly come from non-intact families, and are more prone to experience consistent economic disadvantages (McKeever \& Wolfinger, 2012). This applies to both single mother family structures of never-married and divorced mothers. More so, the single motherhood and economic disadvantage are combined through a dyadic relationship. The preset socioeconomic characteristics also contribute to owning single motherhood and viś-a-viś economic disadvantages that has been attributed to low income and poor social capital endowments. 
Families characterized by single motherhood ascertain the analytical explanation that regardless of the economic position, economic disadvantage is not explained by family structure in and of itself. It is the presence of working adults or employed adults that is significant for healthy family functioning (McKeever \& Wolfinger, 2012). It is argued that both never-married and divorced mothers have chronic disadvantages when it comes to economic costs. Findings from a nationally representative population sample indicate that married mothers are likely to have more income compared to divorce and never-married mothers. Extending unemployment as a determinant of within and beyond income, the economic health of the never married and divorced mothers is explained on the basis of not only simply employment, but also, simultaneously, by human capital advancements.

While parental unemployment can lead to an abundance of negative consequences, intergenerational unemployment data, similarly, point towards risk associated with adolescent psychological well-being especially when youths are going through the transition into adulthood. For example, a study showed that youth unemployment in combination with parental financial support can lead to low levels of youth self-efficacy and depletion in personal psychological wellbeing (Mortimer, Kim, Staff, \& Vuolo, 2016) or low self-worth.

Perceptions of economic hardships can also lead to poor lifestyle experiences. Findings from a nationally representative data from Portugal, which was severely hit by the economic recession within the overall European context, show that adolescents who perceived negative lifestyle consequences of economic recession, tended to have poor lifestyle consequences of life satisfaction. As Portugal does not have well defined unemployment benefit welfare for its citizens, family job loss and low level of perceived family wealth among adolescents were expected to show low or poor lifestyle changes. The longer the experiences of job loss lasted, worst results of youth development and welfare effects were found (Frasquilho, de Matos, Gaspar, \& de Almeida, 2016). The same study illustrated that depending upon families income level and trend of that income overtime, income instability can have variable and detrimental consequences for children's well-being (Frasquilho, de Matos, Gaspar, \& de Almeida, 2016; Hill, Gennetian, Wolf, \& Tubbs, 2013). To slightly contradict this finding, research has also indicated an alternative pathway to relatively less damaging outcomes of young adult's livelihood during economic hardships. The two to three years of after effects of great recession data indicated that the young adults experiencing financial crisis went out to start living with either romantic partners or with friends. After the 1980s a great number of unmarried adults remained intact or returned back to their parental households. Overall this finding states that the Great Recession did not weaken family life (Cherlin, Cumberworth, Morgan, \& Wimer, 2013).

When faced with the challenges of job loss, families try out several mechanisms to maintain well-being. Doubling up is one of those techniques by which individuals move back to their families. During the periods of unemployment, doubling up and moving back with the families is likely to increase three times more than those who have jobs (Wiemers, 2014). Moving 
back to shared living arrangements is mostly found among individuals with less than high school diploma and some with at least some college experience. While people with higher levels of education have been found to move in mostly with parents and roommates, individuals with low education move in with a variety of different arrangements (Wiemers, 2014). Another mechanism that buffered the prolonged severity of joblessness was mediated and normalized by the choice of communication style, which is primarily supposed to be resilient (Beck, 2016).

\section{References}

Adler, N. E., \& Ostrove, J. M. (1999). Socioeconomic status and health: What we know and what we don't. Annals of the New York Academy of Sciences, 896, 3-16. DOI: 10.1111/j.1749-6632.1999.tb08101.x

Artazcoz, L., Benach, J., Borrell, C., \& Cortes, I. (2004). Unemployment and mental health: understanding the interactions among gender, family roles, and social class. American Journal of Public Health, 94, 82-88. DOI: 10.2105/AJPH.94.1.82

Beck, G. A. (2016). Surviving involuntary unemployment together: The role of resilience-promoting communication in familial and committed relationships. Journal of Family Communication, 16(4), 369-385. DOI: 10.1080/15267431.2016.1215315

Broman, C.L., Hamilton, V.L., \& Hoffman, W.S. (1990) Unemployment and its effects on families: Evidence from a plant closing study. American Journal of Community Psychiatry, 18(5), 643-659. DOI: 10.1007/BF00931235

Cherlin, A., Cumberworth, E., Morgan, S. P., \& Wimer, C. (2013). The effects of the Great Recession on family structure and fertility. The ANNALS of the American Academy of Political and Social Science, 650(1), 214-231. DOI: 10.1177/0002716213500643

Coker, A.L., Smith, P.H., McKeown, R.E. \& King, M.J. (2000). Frequency and correlates of intimate partner violence by type: Physical, sexual, and psychological battering. American Journal of Public Health, 90(4), 553-559. DOI: 10.2105/AJPH.90.4.553

Conger, R. D., Ge, X., Elder, G. H., Jr., Lorenz, E O., \& Simons, R. L. (1994). Economic stress, coercive family process and developmental problems of adolescents [Special issue on children and poverty]. Child Development, 65, 541-561. DOI: 10.1111/j.1467-8624.1994.tb00768.x

Conger, R.D. \& Conger, K.J. (2002). Resilience in Midwestern families: Selected findings from a decade of a prospective longitudinal study. Journal of Marriage and Family, 64(2), 361-373. DOI: 10.1111/j.17413737.2002.00361.x

Doiron, D., \& Mendolia, S. (2012). The impact of job loss on family dissolution. Journal of Population Economics, 25(1), 367-398.

Dooley, D., Fielding, J., \& Levi, L. (1996). Health and unemployment. Annual Review of Public Health. 17, 449-465. DOI: 10.1146/annurev.pu.17.050196.002313 
Edler, G. \& Caspi, A. (1988). Economic Stress in Lives: Developmental Perspectives. Journal of Social Issues, 44(4), 25-45. DOI: 10.1111/j.15404560.1988.tb02090.x

Eliason, M. (2012). Lost jobs, broken marriages. Journal of Population Economics, 25(4), 1365-1397.

Frasquilho, D., de Matos, M. G., Gaspar, T., \& de Almeida, J. C. (2016). Young people's well-being and the economic crisis: How does parental unemployment and family wealth affect the downturn experience? Children and Youth Services Review, 69, 219-222. DOI: 10.1016/j.childyouth.2016.08.018

Fox, G.L., Benson, M.L., DeMaris, A.A., \& Van Wyk, J. (2002) Economic distress and intimate violence: Testing family stress and resource theories. Journal of Marriage and Family, 64(3), 793-807. DOI: 10.1111/j.17413737.2002.00793.x

Gore, S. (1978). The effect of social support in moderating the health consequences of unemployment. Journal of Health and Social Behavior, 19(2), 157-165. DOI: 10.2307/2136531

Hamilton, V.L., Broman, C.L., Hoffman, W.S., \& Renner, D.S. (1990). Hard times and vulnerable people: Initial effects of plant closing on auto workers' mental health. Journal of Health and Social Behavior, 31, 123140. DOI: $10.2307 / 2137167$

Hill, H. D., Morris, P., Gennetian, L. A., Wolf, S., \& Tubbs, C. (2013). The consequences of income instability for children's well-being. Child Development Perspectives, 7(2), 85-90. DOI: 10.1111/cdep.12018

Kessler, R.C., Turner, J.B., \& House, J.S. (1987). Unemployment and health in a community sample. Journal of Health and Social Behavior, 28(1), 51-59.

McKeever, M., \& Nicholas, H. W. (2012). Over the long haul: The persistent economic consequences of single motherhood. In Blair Sampson Lee (Ed.), Economic stress and the family (Vol. 6; pp.1-39). Emerald Group Publishing: New York. DOI: 10.1108/S1530-3535(2012)0000006004

MacInnes, M. D., \& Broman, C. (2012). The impact of fragile economy on the well-being of Michiganians and their families. In Blair Sampson Lee (Ed.), Economic stress and the family (Vol. 6; pp.41-57). Emerald Group Publishing: New York. DOI: 10.1108/S1530-3535(2012)0000006005

McLoyd, V. C. (1990). The Impact of Economic Hardship on Black Families and Children: Psychological Distress, Parenting, and Socioemotional Development. Child Development, 61, 311-346.

McLoyd, V.C., Jayaratne, T.E., Ceballo, R. \& Borquez, J. (1994). Unemployment and work interruption and African American single mothers: Effects of parenting and adolescent socioemotional functioning. Child Development, 65(2), 562-589.

Nichols, A., Mitchell, J., \& Lindner, S. (2013). Consequences of long-term unemployment. Washington, DC: The Urban Institute.

Paul, K.L., \& Moser, K. (2009). Unemployment impairs mental health: Metaanalyses. Journal of Vocational Behavior, 74, 264-282. 
Price, R.H., Choi, J.N., \& Vinkkur, A.D. (2002). Links in the chain of adversity following job loss: How financial strain and loss of personal control lead to depression, impaired functioning, and poor health. Journal of Occupational Health Psychology, 7(4), 302-312. DOI: 10.1037//10768998.7.4.302

Selye, H. (1956). The stress of life. New York: McGraw-Hill.

Selye, H. (1976). Stress in health and disease. Boston: Butterworth.

Starkley, J.L. (1996) Race Differences in the Effect of Unemployment on Marital Instability: A Socioeconomic Analysis. Journal of Socio-Economics, 25(6): 683-720.Straus, M. A., Gelles, R.

Straus, M.A., Gelles, R.J., \& Steinmetz, S. K. (1980). Behind closed doors: Violence in the American family. Garden City, NJ: Doubleday.

Takeuchi, D., Williams, D.R. \& Adair, R.K. (1991). Economic Stress in the family and children's emotional and behavioral problems. Journal of Marriage and Family, 53(4), 1031-1041. DOI: 10.2307/353006.

Townsend, N.W. (2002). The package deal: Marriage, work and fatherhood in men's lives. Philadelphia: Temple University Press.

Tumin, D., \& Qian, Z. (2015). Unemployment and the Transition from Separation to Divorce. Journal of Family Issues, 1-25.

DOI: $10.1177 / 0192513 X 15600730$

Van der Meer, P. H. (2014). Gender, unemployment and subjective well-being: Why being unemployed is worse for men than for women. Social Indicators Research, 115(1), 23-44. DOI:10.1007/s11205-012-0207-5

Voyandoff, P. (1990). Economic distress and family relations: A Review of the Eighties. Journal of Marriage and Family, 52(4), 1099-1115. DOI: $10.2307 / 353321$

Wiemers, E. E. (2014). The effect of unemployment on household composition and doubling up. Demography, 51(6), 2155-2178. DOI: 10.1007/s13524014-0347-0 